Scholarship Repository

University of Minnesota Law School

Articles

Faculty Scholarship

1995

\title{
Lessons of State Guideline Reforms
}

Richard Frase

University of Minnesota Law School, frase001@umn.edu

Follow this and additional works at: https://scholarship.law.umn.edu/faculty_articles

Part of the Law Commons

\section{Recommended Citation}

Richard Frase, Lessons of State Guideline Reforms, 8 FED. SENTENCING R. 39 (1995), available at https://scholarship.law.umn.edu/faculty_articles/516.

This Article is brought to you for free and open access by the University of Minnesota Law School. It has been accepted for inclusion in the Faculty Scholarship collection by an authorized administrator of the Scholarship Repository. For more information, please contact lenzx009@umn.edu. 


\section{LESSONS OF STATE GUIDELINE REFORMS}

\section{Richard S. Frase*}

As the Sentencing Commission plans for the future of guidelines in the federal courts, it should consider the experience of the growing number of states with guideline systems. Ten states already had guidelines when the federal reform took effect in November 1987; since then, seven more have implemented guidelines, and another six have appointed commissions to implement or study this approach. ${ }^{1}$

State guidelines have become increasingly sophisticated, as later reformers built upon and learned from the experiences of the states that went before. A number of states have also looked to the federal experience, usually in an attempt to avoid problems which have made the federal version highly controversial. ${ }^{2}$

State guidelines are very diverse in their origins, purposes, and specific provisions, but they also have many features in common. Some of the most important features of state systems also serve to distinguish them from the federal guidelines. First, state guidelines tend to permit more judicial discretion (especially in the assessment of offender characteristics), and are less constrained by mandatory minimum sentencing statutes. Second, all state guideline systems (as well as the recently-revised ABA Sentencing Standards) ${ }^{3}$ reject routine sentence enhancements based on unconvicted, "real offense" factors. Third, state guideline reforms are increasingly motivated by a desire to gain better control over escalating prison populations; several states (and the ABA Standards) directly link guideline sentences to available correctional resources. Fourth, the focus on prison capacity limits has encouraged state reformers to give increasing emphasis to the development and structuring of non-prison sanctions, especially for non-violent or first offenders. Fifth, as a result of the above features and other policy decisions, state guideline systems have generally achieved broad acceptance by judges and attorneys.

In the remainder of this essay, I would like to focus on the third feature of state guidelines identified above - the concept of linking sentencing policy with correctional resources. Minnesota pioneered this approach in 1980, when its sentencing commission adopted a goal of never exceeding $95 \%$ of state prison capacity. The Minnesota Commission achieved this goal throughout the 1980 s - a period in which most other states were experiencing rapid, uncontrolled growth in prison populations, often resulting in

* Benjamin N. Berger Professor of Criminal Law, University of Minnesota. serious overcrowding, court intervention, and the need to grant early release to many inmates. ${ }^{4}$

The 1984 federal enabling statute directed the Sentencing Commission to take existing correctional resources into account, and mandated that guidelines be formulated so as to "minimize the likelihood" of federal prison overcrowding. ${ }^{5}$ However, the Commission did not take this directive seriously in formulating the initial guidelines. Detailed prison impact assessments were not completed until after the new guidelines had been submitted to Congress, ${ }^{6}$ and prison capacity management has never even been mentioned by the Commission as a reform goal.

Indeed, instead of helping to reduce the serious overcrowding which already existed in 1987,7 the guidelines made the problem worse - the Commission projected that its new guidelines would further increase federal prison populations. ${ }^{8}$ As a combined result of the Commission's guidelines, changing federal caseloads, and increasingly severe sentencing laws, the federal prison population has more than doubled since 1987, and continues to greatly exceed capacity. ${ }^{9}$ It is true that officially-reported measures of federal prison overcrowding have declined since $1987,{ }^{10}$ but this was achieved only through a massive building program - expected to almost quadruple capacity by the year $2000 .{ }^{11}$ Furthermore, some of the "improvement" in overcrowding rates appears to reflect changing definitions of "capacity."12

Since the federal guidelines became effective, more and more states have begun to view guidelines as a means of gaining control over escalating prison populations and correctional expenses. At present, nineteen states have enacted statutes which require or at least strongly encourage matching sentencing policy to available resources. ${ }^{13}$ Guidelines permit such resource-matching because they make prison commitment and prison duration decisions more uniform. This greater uniformity allows policy makers to know more precisely how much prison space will be required to implement existing or proposed sentencing laws, and how soon that space will be needed. Armed with this information, legislators can begin the often lengthy process of expanding prison capacity early enough to meet the expected need and avoid overcrowding.

But legislators and sentencing commissioners can also use population projections to make other choices: they can reduce the predicted demand by moderating penalty increases, by lowering existing penalties for certain offenders, or by a combination of these approaches. Accurate predictions of the full cost of current and proposed sentencing laws thus play an important role in formulating sentencing policy - by forcing policy makers and the public to confront the full costs of politically popular increases in sentencing severity.

Especially in the angry, tough-on-crime climate of recent years, capacity-based sentencing policy 
introduces a much-needed sense of fiscal responsibility, and emphasizes the inescapable need to set priorities in allocating limited and expensive prison resources. Proponents of particular "get tough" measures can be told more precisely what these measures will cost, and can then be asked to show how these measures will be paid for-whether through increased taxes, cuts in existing programs, or reduced severity toward other offenders. Linking sentencing policy to available resources also encourages commissioners and legislators to take a comprehensive view of sentencing policy: Which offenders require secure detention? For those who do not, what non-custodial sanctions are available to hold offenders accountable, deter crime, facilitate rehabilitation, and promote victim and community restitution?

Linking sentencing policy to resources does not necessarily mean "zero population growth" in state prisons, but it encourages more controlled growth. Minnesota's prison population has more than doubled since 1980, but the increase was slow enough, and was foreseen far enough in advance, to permit timely expansion of prison capacity and prevent serious overcrowding.

As efforts to balance the federal budget intensify, Congress may be coming to realize the importance of limiting prison population growth and linking sentencing policy to correctional resources. The 1994 Crime Bill contains a provision requiring all legislation proposed by the Judicial or Executive branch that would increase or decrease the number of federal inmates to include a "prison impact" assessment, showing the expected effect on prison and probation populations and federal expenditures for the current and next five succeeding fiscal years. ${ }^{14}$

The Sentencing Commission and the Bureau of Prisons already have the capability to provide detailed prison impact assessments, using their extensive sentencing and correctional databases. Such assessments have been provided for at least some crime bills and Commission proposals. ${ }^{15}$ The Commission should seek to further refine its prediction model with input from the guideline states. Many states have now developed sophisticated computerized models, incorporating presumptive sentences, current and expected caseloads, and other variables which determine the size of inmate populations.

The Sentencing Commission should apply its population-impact model to all major crime bills including those originating in the Legislative branch. ${ }^{16}$ Impact assessments should also be made prior to adoption of proposed guideline amendments (as was mandated by the enabling statute). ${ }^{17}$ If the net effect of any Commission proposal would be to further increase federal prison overcrowding relative to current and projected (i.e., already-funded) prison capacity, the Commission should modify its proposal, and/or suggest other guideline amendments to eliminate the projected increase in overcrowding. And if Congress does not appropriate the funds needed to reduce and eventually eliminate overcrowding, ${ }^{18}$ the Commission should take the initiative - by announcing the reductions in presumptive sentences which it will make, to bring inmate populations and capacity back into balance. Reductions in presumptive sentences should also be recommended whenever needed to compensate for increased overcrowding which is expected to result from previously-adopted legislation, guidelines provisions, and/or rising caseloads.

Resource-matching policies of the type described above have enabled state guidelines systems to prevent uncontrolled growth in prison populations and expenses, avoid overcrowding, and, in several states, reduce overcrowding which already existed when the guidelines were adopted. ${ }^{19}$ Resourcematching has also served to promote more responsible and rational sentencing policy, and has encouraged broader use of intermediate sanctions. ${ }^{20}$ As the guidelines states have worked to slow or reverse the growth in prison populations, they have discovered that many offenders previously sent to prison did not need to be there.

It is time for the Sentencing Commission to follow suit. Many federal inmates do not need to be in prison, and federal prison populations do not need to continue their rapid growth. Moreover, the Commission should no longer assume, as it has in the past, that Congress will appropriate funds to pay for any and all increases in sentencing severity. Until now, Congress has essentially given the Commission a blank check, but this "pay-whatever-it-costs" policy may not continue in the current era of greatly increased scrutiny of federal budgets and deficitspending.

Even if Congress continues to sign all of the Commission's checks, the Commission has a responsibility to provide its own independent, expert assessment of whether such expenditures are necessary and wise. The increased emphasis on noncustodial sentencing alternatives in the guidelines states reflects a growing confidence that such intermediate sanctions can provide effective and less costly punishment. The experience of the states also suggests that custodial penalties are being significantly overused in the federal system. ${ }^{21}$

\section{FOOTNOTES}

1 The most recent state to consider guidelines is Montana. 1995 Mont. Laws, ch. 306. The guidelines reforms in 22 other states, as of late 1994, are summarized in Frase, State Sentencing Guidelines: Still Going Strong, 78 Judicature 173-79 (1995). See also 6 Fed. Sent. R. 129-79 (1993) (essays describing guideline experiences in nine 
states); Tonry, Sentencing Commissions and Their Guidelines, 17 Crime and Just. 137-95 (1993).

${ }^{2}$ See, e.g., 6 Fed. Sent. R. at 129-30 and 141 (reformers in North Carolina and Texas rejected federal guidelines as a model).

${ }^{3}$ American Bar Association, Standards for Criminal Justice, Sentencing (3rd Edit., 1994), Standard 18-3.6.

4 See Frase, Sentencing Guidelines in Minnesota and Other American States: A Progress Report, in The Politics of Sentencing Reform (Chris Clarkson \& Rod Morgan, Eds.) (Oxford University Press, 1995) at 192-97; Frase, Implementing Commission-based Sentencing Guidelines: The Lessons of the First Ten Years in Minnesota, 2 Cornell J. L. \& Pub. Pol. 279, 329-33 (1993).

${ }^{5} 18$ U.S.C. $\$ 994(\mathrm{~g})$.

6 See U.S. Sent. Comm., Supplemental Report on the Initial Sentencing Guidelines and Policy Statements (1987) pp 53-75; Gaes, Simon, \& Rhodes, 20/20 Hindsight: Effectiveness of Simulating the Impact of Federal Sentencing Legislation on the Future Prison Population, 73 Prison Journal 5, 17 (1993).

7 See U.S. Dept. of Just., Bur. of Just. Stat., Bulletin: Prisoners in 1987 (1988), pp. 2, 5, 7 (total federal inmate population at year-end, 1987 was 48,300 , which represented $173 \%$ of the rated capacity of federal institutions). The occupancy rate is lower if only the inmates held in federal institutions are counted (i.e., excluding inmates boarded in contract facilities). See U.S. Dept. of Just., Annual Report of the Attorney General of the United States, 1987, at 12-14 (on September 30,1987 , the 44,194 inmates held in federal institutions represented $159 \%$ of rated capacity).

${ }^{8}$ U.S. Sent. Comm., supra note 6. Although the Commission claimed that the marginal impact of the Guidelines was minor, some scholars have argued that the Commission exaggerated the effect of previously-enacted sentencing laws, and understated the independent impact of the Guidelines. See von Hirsch, Federal Sentencing Guidelines: The United States and Canadian Schemes Compared (N.Y. Univ. Law Sch., 1988), at pp. 6-7. See also U.S. Sent. Comm., 1989 Annual Report (1990), p. 66 (guidelines changes accounted for $72 \%$ of the projected $6.7 \%$ increase in time-served).

${ }^{9}$ As of December 31, 1987, the total federal inmate population (including inmates held in contract facilities) was 48,300 . Bur. Of Just. Stat., Bulletin supra note 7, at 2. As of June 15, 1995, the total inmate population had risen to 99,192 , which represented $139 \%$ of the rated capacity of federally-operated facilites; 89,120 of these inmates were held in federal facilities, representing $125 \%$ of the rated capacity of those facilities (1995 figures supplied by Office of Research and Evaluation, U.S. Bureau of Prisons).

10 Between year-end, 1987, and June 15, 1995, total federal inmates as a percent of federal prison and jail rated capacity decreased from $173 \%$ to $139 \%$; if inmates boarded in contract facilities are excluded, the 1987 year-end occupancy rate would have been about $160 \%$, decreasing to $125 \%$ in 1995. See supra notes 7 and 9 . As of June 15, 1995, about 10,000 federal inmates were boarded in contract facilities.
11 At year-end, 1987, rated capacity stood at 27,854. Bur. of Just. Stat., Bulletin, supra note 7, at 5. Capacity as of June 15,1995 was 71,139 , and is expected to be 107,435 , by 2000 (figures supplied by Office of Research and Evaluation, U.S. Bureau of Prisons).

12 Cf. Franklin Zimring, Are State Prisons Undercrowded?, 4 Fed. Sent. R. 347 (1992), noting the tendency of states to expand "capacity" by redefining it (e.g., by claiming that existing one-man cells were "designed" for two prisoners). See also U.S. Gen. Acctg. Off., Federal Prison Expansion: Overcrowding Reduced but Inmate Population Growth May Raise Issue Again (1993) at 1, 7-9, noting increased use of double-bunking in existing as well as new federal prisons.

${ }^{13}$ See Frase, supra note 1, at 174, Table 1; 1995 Montana Laws, ch. $306, \S 3$.

${ }_{14}$ Violent Crime Control and Law Enforcement Act of 1994 , $§ 20402$, to be codified at 18 U.S.C. $\S 4047$. Unfortunately, this provision is only optional, when bills are submitted within the Legislative branch, and it does not appear to apply to proposed changes in the guidelines; moreover, the provision does not clearly require a detailed assessment of the impact on other components of the criminal justice system (i.e., law enforcement, courts, prosecutors, and defenders). See Miller, Rehabilitating the Federal Sentencing Guidelines, 78 Judicature 180, 187-88 (1995).

${ }^{15}$ See, e.g., U.S. Sent. Comm., 1994 Annual Report152-53 (1995). The federal prison population projection model is described in Gaes et al., supra note 6.

${ }^{16}$ See supra note 14.

17 See supra note 5 and accompanying text.

${ }^{18}$ The massive prison-expansion program already funded by Congress is expected to reduce federal prison overcrowding to about 9 percent, by the year 2000 (figures supplied by the Bureau of Prisons Office of Research and Evaluation). According to official statistics, federal prisons are currently $25 \%$ overcrowded. See supra notes $9 \& 12$.

19 See, e.g., Thomas Marvel, Sentencing Guidelines and Prison Population Growth, 85 J. Crim. L. \& Criminol. (1995) (forthcoming). For examples of the Minnesota Sentencing Guidelines Commission's efforts to control prison overcrowding and overuse, see Dale Parent, Structuring Criminal Sentences (1988), at pp. 6-7, 40-45, 92-93, \& 107.

${ }^{20}$ See generally, Morris \& Tonry, Between Prison and Probation: Intermediate Punishments in a Rational Sentencing System (1990).

${ }_{21}$ Compare U.S. Sent. Comm., supra note 15 , at 53 (14.4\% of federal defendants received straight probation in fiscal year 1994) with U.S. Dept. of Just., Bur. of Just. Stat., Felony Sentences in State Courts, 1992, at 2 (straight probation rate, including non-guideline states, was $30 \%$, in 1992). 